\title{
Voluntary national SDG reviews as a new reporting institution in a globalized society
}

\author{
Andrew V. Novikov ${ }^{1,}$, Vladimir Sh. Urazgaliev ${ }^{1}$, Galina A. Menshikova ${ }^{2}$, and Alexander N. \\ Soshnev ${ }^{2}$ \\ ${ }^{1}$ Saint Petersburg State University, Faculty of Economics, Department of Economics \& Economic \\ Policy, University embankment 7-9, 199034, St Petersburg, Russia \\ ${ }^{2}$ St.Petersburg State University, Faculty of Sociology, 7/9 Universitetskaya nab., St. Petersburg, \\ 199034 Russia
}

\begin{abstract}
Research background: Having recognized the SDGs as the most important direction of globalization processes' implementation, we point out that assessing the results of world progress in this direction is important both in terms of assessing its dynamics and as a new technology of global governance. Assessment (both as an institution and as a management technology) is a new type of analytical and coordination interactions between countries, which is just beginning to emerge.

Purpose of the article: The publication has three goals. The first is to present Voluntary national SDG reviews (VNRs) as an emerging institution for assessing and managing of global development. The second is to describe methodological approaches of their assessment, presenting them as a continuous improvement of methodology and methods that reflect new requirements for the VNRs analyses. The third is to assess the VNR of the RF (Russian Federation) - 2020, taking into account official and unofficial judgments, views from within and external experts.

Methods: The publication as a whole follows an institutional approach. It provides a comparative generalization of methodological approaches to the VNRs assessment, presents expert judgments that allow to outline the compliance of VNR RF-2020 with the new valuation principles

Findings \& Value added:: The publication will present a general scheme of VNR institutional understanding, a comparative analysis of traditional and new methodologies for their assessment and will propose systematic (comprehensive) assessment of VNR RF-2020.
\end{abstract}

Keywords: voluntary national reviews, institutionalization, comparative analysis of assessment methodologies, comprehensive assessment of the VNR RF-2020

JEL Classification: 011, 044, Q01

\footnotetext{
* Corresponding author: a-novikov@mail.ru
} 


\section{Introduction}

The Sustainable Development Goals are the most important area that implements the intention to globalize. Almost all countries (193 states) have signed the SDG Agreement, thereby expressing their readiness for global modernization, formulated it in the form of the "Transforming our world: the 2030 Agenda for Sustainable Development". In addition to achieving the 17 goals that make up its content, the technologies of their implementation are also of great interest for science as the establishment of international relations of a new type. The SDGs are the new and most massively managed process of global restructuring of national, regional and corporate interests. Scientists, evaluating its role, write: 'SDGs were developed not by a growing group of experts but by an unprecedented global priority-setting process, engaging more than a million people around the world through global surveys, reports and consultations in nearly 100 countries" (Friedman \& Gostin, 2016; United Nations, 2019).

10 years have passed since the SDGs were formulated as a UN Resolution in June 2012, and 7.5 years have passed since the start of implementation (01.01.2016), i.e. half way passed. It is possible and necessary to evaluate the results, to determine successes and failures, identifying obstacles to the achievement of the tasks set (Breuer \& Leininger, 2021), (Allen et al., 2021). It is clear that a critical approach dominates in statements, since this is how weaknesses are identified, ways to eliminate them are outlined. Officials and academics are both critical. Thus, at the High-Level Political Forum (HLPF), designed to take stock of some results, the UN Secretary-General indicated that "the shift in development paths to ensure the transformations necessary to achieve the SDGs by 2030 is not yet happening at the required speed or scale ${ }^{\dagger} . "$

\section{VNR as a social institution for managing and assessing the progress of countries' development towards achieving the SDGs}

VNRs are the core reporting and evaluation technology of countries' interaction with the UN. According to the recommendations, countries should provide at least two of them for the "Agenda" period, but many states (50 out of 153), which mostly belong to the "developed" cluster, make them up annually; some, for example Argentina, Armenia, Bangladesh, Finland, India - have already prepared two reports, and Togo and Benin - three times. RF submitted one review to the UN.

VNR is an official government document that records its successes and failures on the way to implementing the SDGs. They are represented at the UN HLPF. As a management technology, VNRs began to be implemented within the framework of the new course, which significantly distinguishes it from the previous stage - "The Millennium Development Goals".

Reflecting a common line on the democratization of governance, they are the product of state leader's collective creativity, government officials, expert and scientific organizations and representatives of civil society. At the same time, researchers use also other forms of obtaining information about the country's development: national statistics, interviews with experts and politicians, public discussion platforms $\$$.

With relative uniformity in the preparation of the report: voluntariness in the choice of timelines, self-selection of facts and illustrative cases (within the framework of 17 goals and

\footnotetext{
$\dagger$ IISD. UN Officials Highlight Findings of 2019 SDG Progress Report SDG Knowledge Hub 2019.

* According to the data, by 2019 there were 36 platforms in the SDG field
} 
237 recorded indicators), the methods and subjects of their assessment are diverse, which reflects the complexity of the SDG implementation guiding system and the variety of tasks within the 17 SDGs. So, the overall results of countries (regions, cities) are assessed and then summarized in the form of compiling their ranking according to the progress index (SDG Index). Rating helps to identify the successes / failures for each goal and to highlight examples of best practices or the reasons for the difficulties encountered. As the new global strategy is being formed, more and less active regions are identified, which predetermined the main difficulty - to assess the desire of the top leadership of the countries to modernize the goals of national development, including political attitudes. Accordingly, at the turning point, it is the management aspects that come to the fore, which predetermines the need to create new assessment methodologies. They are intended to characterize both the degree of government activity in the implementation of the SDGs and the involvement of business and civil society in achieving results (Bickler et al., 2020 ; Allen et al., 2018; Dickens et al., 2019)

Taking into account the volume and multifactorial nature of the information collected in VNRs of different countries, many agencies and expert groups have reoriented their traditional activities towards the SDGs. Along with UN and OECD experts, VNR joined the audit International supreme audit institutions (INTOSAI), Inter-Agency and Expert Group, etc.

So, the VNR is an emerging social institution for reporting and evaluating the achievement of the SDGs. They are intended to become a mass and comprehensive practice, as it is planned to extend their obligation to regions, cities and enterprises. Difficulties in the implementation of the last statement are reflected in the publications: (Lundan \& Cantwell, 2020; Don, 2021; Montiel, 2021; Ghoul, 2017). VNR is a natural part of the global democratic trend in governance, since the completeness of goals implementation can be achieved only if the SDGs are covered by the entire national social system. The development of VNRs is proceeding in many directions: insignificantly, but the system of reporting indicators is being refined, assessment methods are being improved, and forms of strengthening accountability are being sought.

\section{VNR assessment: directions of criticism and improvement of methodology}

It seems that criticism of the activities of the UN leadership and national governments is the main way of managing the implementation of the SDGs. There are many critics, but, in our opinion, this should be perceived as a lively interest, as a constructive approach.

As for the VNR, their main critical directions are still reporting indicators (someone is against of a unified system, someone does not see directly among them indicators of SDG manageability, there are many other proposals and comments (Böhringer \& Jochem, 2007), but the main thing is excessive tolerance in the assessment, the lack of a mechanism of responsibility for the accuracy of the given data, etc. (Sachs et al., 2020). The Bartelsmann Foundation also found financial insufficiency - funds that were promised were not received (UNCTAD, 2014). The focus of researchers' activity has shifted to the development of methodological techniques in assessing VNR, see Table 1.

Table 1. Some trends in improving the VNR assessment methodology of the total volume of exports / imports

\begin{tabular}{|l|l|}
\hline Methodology's definition & Features of the methodology \\
\hline $\begin{array}{l}\text { 1.Basic methodology for reporting } \\
\text { on countries' progress on the } \\
\text { SDGs. }\end{array}$ & $\begin{array}{l}\text { It was developed by the UN Interdepartmental Expert } \\
\text { Group on SDG Indicators. All countries collect information } \\
\text { on 237 indicators common to all, characterizing 169 targets }\end{array}$ \\
\hline
\end{tabular}




\begin{tabular}{|c|c|}
\hline & $\begin{array}{l}\text { within the } 17 \text { goals. The UN Statistical Center summarizes } \\
\text { the results, assessing the degree of approximation to the set } \\
\text { goals. }\end{array}$ \\
\hline $\begin{array}{l}\text { 2. Creation of an adequate } \\
\text { statistical base (under the } \\
\text { leadership of the UN statistics } \\
\text { department, in cooperation with } \\
\text { regional and national } \\
\text { organizations) (United Nations } \\
\text { 2019). }\end{array}$ & $\begin{array}{l}\text { Formation of reliable information flows collected according } \\
\text { to a unified methodology. For this, all indicators were ranked } \\
\text { according to three levels: widely used statistical information } \\
\text { (1), the methodology is clear, but the collection practice has } \\
\text { only recently been formed } \quad(2) \text {, there is even no } \\
\text { understanding of the indicator methodology (3). }\end{array}$ \\
\hline 3. UN Global list indicator & $\begin{array}{l}\text { The first modification of the basic UN methodology. It } \\
\text { adjusts the result taking into account the population in the } \\
\text { country, region }\end{array}$ \\
\hline $\begin{array}{l}\text { 4. SCI assessment of mutual } \\
\text { influence of goals, OECD } \\
\text { (Measuring Distance to the SDG } \\
\text { Targets, 2019; Sachs et al. 2017). }\end{array}$ & $\begin{array}{l}\text { Based on the analysis of } 316 \text { interactions at the target level, } \\
\text { positive (236), negative (66) and neutral (12) were } \\
\text { identified, and through further systematic assessment, four } \\
\text { goals (SDGs } 2,3,7 \text { and 14) were identified, which are } \\
\text { considered synergistic. }\end{array}$ \\
\hline $\begin{array}{l}\text { 5.Independent international } \\
\text { rankings published annually in the } \\
\text { form of the SDG Index (Doumbia, } \\
\text { Lauridsen, 2019) }\end{array}$ & $\begin{array}{l}\text { The indicators are divided into main groups: social, } \\
\text { economic, environmental and institutional aspects of } \\
\text { sustainable development. The assessment is carried out on a } \\
100 \text { point system. It is complemented by the independent } \\
\text { collection of national statistical sources by experts, a survey } \\
\text { of politicians and heads of government bodies, a review of } \\
\text { publications and reports, judgments of NGOs and the } \\
\text { population. } \\
\text { The assessment is carried out by specialists from SDSN } \\
\text { (Decision Making Network) and the German Bertelsmann } \\
\text { Foundation. }\end{array}$ \\
\hline $\begin{array}{l}\text { 6. An attempt to analyze the } \\
\text { effectiveness of the SDGs OECD } \\
\text { (Weber, 2018; Guidance on audit } \\
\text { for the Development and use of } \\
\text { Key national Indicators GUID- } \\
5290,2019 \text { ) }\end{array}$ & $\begin{array}{l}\text { There were identified and specified in the indicator system } \\
\text { three principles: 1.effectiveness (competence, sound } \\
\text { policymaking, collaboration), 2. accountability (integrity, } \\
\text { transparency, independent oversight), 3. inclusiveness } \\
\text { (leaving no one behind, non- discrimination, participation, } \\
\text { subsidiarity, intergenerational equity) }\end{array}$ \\
\hline $\begin{array}{l}\text { 7. Involvement of traditional audit } \\
\text { methodology for SDGs (Practical } \\
\text { guidebook on data disaggregation } \\
\text { for the SDGs-E, 2021) developed } \\
\text { by the Supreme Audit Institution } \\
\text { (SAI) as part of the strategic plan- } \\
\text { INTOSAI }\end{array}$ & $\begin{array}{l}\text { Key assessment indicators are what the government selected } \\
\text { when compiling the report. In parallel, it is recommended to } \\
\text { evaluate VNR according to } 6 \text { criteria in assessment: of the } \\
\text { legal and methodological basis for the system for measuring } \\
\text { efficiency and impact; of the sufficiency and relevance of a } \\
\text { set of indicators; the quality of a set of indicators; the } \\
\text { consistency of the performance and impact measurement } \\
\text { system with other activities; of the feasibility and validity of } \\
\text { the values of the indicators; of the monitoring and } \\
\text { evaluation procedures adequacy applied in the system for } \\
\text { measuring effectiveness and impact. }\end{array}$ \\
\hline $\begin{array}{l}\text { 8. Following the course on } \\
\text { openness of information, the } \\
\text { OECD has developed a } \\
\text { methodology - Open, useful and } \\
\text { re-usible data } 2019 \text { (OURdata - } \\
\text { index) (The Center for Open Data } \\
\text { Enterprise and Open Data Watch, } \\
\text { 2019; Implementing the SDGs } \\
\text { during the COVID-19 Pandemic: }\end{array}$ & $\begin{array}{l}\text { The index serves for the development and implementation } \\
\text { of open data policy at the central level and includes three } \\
\text { components: openness of government information and its } \\
\text { intention to attract outside actors (1); availability of portals } \\
\text { with accessible statistical information (2), monitoring of the } \\
\text { openness of government structures (3). It is calculated for } \\
\text { OECD countries The Center for Open Data Enterprise and } \\
\text { Open Data Watch. }\end{array}$ \\
\hline
\end{tabular}




\begin{tabular}{|c|c|}
\hline $\begin{array}{l}\text { Role of governments and Supreme } \\
\text { Audit Institutions, 2020) }\end{array}$ & \\
\hline $\begin{array}{l}\text { 9. INTOSAI seven-stage model to } \\
\text { Government SDG Preparedness } \\
\text { Reviews (Policy Coherence for } \\
\text { Sustainable Development, 2018) }\end{array}$ & $\begin{array}{l}\text { This methodology includes a deeper consideration of the role } \\
\text { of Governments. It is based on: an assessment of political } \\
\text { commitment and recognition of national ownership of the } \\
\text { SDGs; raising public awareness and promoting dialogue } \\
\text { with stakeholders; distribution of responsibilities at the } \\
\text { ministerial or other level; the allocation of appropriate } \\
\text { financial and other resources; establishing accountability } \\
\text { mechanisms. }\end{array}$ \\
\hline $\begin{array}{l}10.7 \text { principles of Policy } \\
\text { Coherence for Sustainable } \\
\text { Development, OЭCP, } 2017 \\
\text { (Collste et al., 2017). }\end{array}$ & $\begin{array}{l}\text { These include: political commitment and leadership; long- } \\
\text { term strategic vision; political integration; nationwide } \\
\text { coordination; subnational interaction (cooperation with } \\
\text { stakeholders); influence on policy and financing; } \\
\text { monitoring, reporting and evaluation }\end{array}$ \\
\hline
\end{tabular}

Analysis of the table shows the variety of assessment methodology and trends in their development. So, if at the beginning the methodology was based on improving the system of indicators, then - the formation of an index of the success of countries and at the present stage the focus of innovation is to assess the quality of SDG management.

\section{VNR RF-2020: duality of internal and external assessments}

VNR RF-2020 is the only reporting public review of the RF, which, on one hand, does not contradict the UN requirements, but on the other hand, it reflects the general approach to the SDGs in the Government of the RF. As a factor of insufficient involvement of the President, one can also consider the fact that the report was presented by the Minister of Economic Development M.G. Reshetnikov.

The attitude to the UN activities on the SDGs and reports is different: against the background of an almost major description of successes that distinguishes the official text, Russian scientists and politicians made critical remarks. In particular, they believe that Russia is somewhat lagging behind in the pace of transition to sustainable development, although it had chances to become one of the world leaders, having adopted the concept back already in 1996.

An intermediate position was taken by the Accounts Chamber - Central official audit Organization in RF. Having assessed the country's readiness to implement the SDGs within the framework of a planned study, it noted that the conjugation of the UN goals with the Russian ones is a positive quality, but pointed out the absence of coordinating centers and an approved government course on the SDGs.

Natalya Churkina spoke with sharper criticism, now directly to the VNR RF -2020. She, having analyzed results in obtaining 17 goals in detail, cited the hushed up problems in each direction: the continuing decline in the standard of living; the Gini coefficient, which has not changed for a long time and is 0.413 ; the minimum dynamics of production, environmental problems: separate waste collection does not become a mass practice, large landfills remain, the uncontrolled utilization of hazardous waste is growing (group 5), etc.

Elena Shakhova, the chairman of the Public Association "Civil Control", pointed out the partial unresolved civil problems. Sidorova T.Y. presented criticism of the environmental dimension of the SDGs. In her opinion, one change in the mechanism of nature management, which is taking place in the country, is not enough. It needs new institutions, new practices, i.e. flexible and efficient management mechanisms.

Here are some external estimates. The first one was formed by the researchers from ECOSOC. Its report noted that for each of the individual SDGs, the country is showing certain positive results. Among the most successful were the efforts to achieve SDGs 1, 4 
and 8. Progress was noted in achieving SDG 13, since the State Duma approved the signing of the Kyoto Protocol, i.e. the country has pledged to reduce carbon emissions.

As a result, lets show the place of the RF in the SDG index: 55-th one in 2018 and 46-th in 2020, which, respectively, in points was estimated as 76.7 and 80.5 out of 100 possible. At the same time, experts noted Goal 1 as achieved, giving it 100 points, Goal 4 (Quality of education) as almost approaching the same level. The specialists put the lowest score on Goal 14 (Conservation of marine ecosystems). Structurally, the indices look like this: "successful" goals: 1, 4 and 17, there is an improvement in the development of goals: 3, 5,6,7,8,9,11 and 16 , there is a stagnation of the process - 2, 13, 14 and 15; information is not available - 10 and 12 .

\section{Conclusions}

Undoubtedly, VNR is a constantly developing institution of management and assessment, which forms a new type of international relations in a globalized society. Reports have become mainstream and are constantly in the public eye.

One of the most noticeable trends in the development of VNR is the improvement of assessment methodologies. The identified 10 areas form a trend to expand the methods and spheres of assessment towards the search for mechanisms to improve the quality of management.

For all the apparent successes, the VNR of the RF reflects the course of the social responsibility of the state, which was formed during the Soviet era. Everything that happens in the country to implement the SDGs, and a lot is being done, happens on an initiative basis, rather spontaneously than institutionally. The main problem of the Russia is the lack of political will of the top leadership and, as a result, the underdevelopment of the institutional consolidation of the implementation of the SDGs.

\section{References}

1. Allen, C., Metternicht, G., \& Wiedmann, T. (2018). Initial progress in implementing the Sustainable Development Goals (SDGs): a review of evidence from countries. Sustainability Science, 13(5), 1453-1467.

2. Allen, C., Metternicht, G., \& Wiedmann, T. (2019). Prioritising SDG targets: assessing baselines, gaps and interlinkages. Sustain Science, 14(2), 421-438.

3. Allen, C., Metternicht, G., \& Wiedmann, T. (2021). Priorities for science to support national implementation of the sustainable development goals: A review of progress and gaps, Sustainable Development, 29(4), 635-652.

4. Bickler, G., Morton, S., \& Menne, B. (2020). Health and sustainable development: an analysis of 20 European voluntary national reviews. Public Health, 180, 180-184.

5. Böhringer, C., \& Jochem, P.E., (2007). Measuring the immeasurable - a survey of sustainability indices. Ecological Economics, 63(1), 1-8.

6. Breuer, A., \& Leininger, J. (2021). Horizontal Accountability for SDG Implementation: A Comparative Cross-National Analysis of Emerging National Accountability Regimes, Sustainability, 13(13), 7002.

7. Collste, D., Pedercini M., \& Cornell, S.E. (2017). Policy coherence to achieve the SDGs: using integrated simulation models to assess effective policies. Sustainability Science, 12(6), 921-931.

8. Dickens, C., Smakhtin, V., McCartney, M., O'Brien, G., \& Dahir, L. (2019). Defining and Quantifying National -Level Targets, Indicators and Benchmarks for Management 
of Natural Resources to Achieve the Sustainable Development Goals. Sustainability, 11(2), 462.

9. Doh, J., Budhar R., \& Wood, J. (2021). Long-term energy transitions and international business: Concepts, theory, methods, and a research agenda. Journal of International Business Studies, 52(5), 951-970.

10. Doumbia, D., \& Lauridsen, M.L. (2019). Closing the SDG Financing Gap - Trends and Data. International Finance Corporation. World Bank Group: Washington, DC.

11. Friedman, A.E., \& Gostin, O.L. (2016). The United Nations Sustainable Development Goals: Achieving the Vision of Global Health with Justice. The Georgetown Public Policy Review, 21(1), 1-25.

12. Ghoul S., Guedhami O., \& Kim Y. (2017). Country-level institutions, firm value, and the role of corporate social responsibility initiatives. Journal of International Business Studies, 48(3), 360-385.

13. Guidance on audit for the Development and use of Key national Indicators GUID-5290. Retrieved from: https://www.issai.org/wp-content/uploads/2019/09/GUID-5290Guidance-on-audit-of-Key-National-Indicators.pdf

14. Implementing the SDGs during the COVID-19 Pandemic: Role of governments and Supreme Audit Institutions (2020). Retrieved from: https://ach.gov.ru/upload/pdf/eng/En-Covid-19-sdg.pdf

15. Lundan, S., \& Cantwell, J. (2020). The local co-evolution of firms and governments in the Information Age. Journal of Intern. Business Studies, 51(9), 1516-1528.

16. Measuring Distance to the SDG Targets (2019). An Assessment of Where OECD Countries Stand. Retrieved from: https://www.oecd.org/sdd/measuring-distance-to-thesdg-targets-2019-a8caf3fa-en.htm.

17. Montiel, I., Cuervo-Cazurra, A., Park, J., Antolin-Lopez R., \& Husted, B. (2021). Implementing the United Nations' Sustainable Development Goals in international business. Journal of International Business Studies, 52(5), 999-1030.

18. Policy Coherence for Sustainable Development (2018). Retrieved from: https://www.oecd.org/gov/pcsd/

19. Practical guidebook on data disaggregation for the SDGs-E. Asian Development Bank (ADB) and the United Nations Statistics Division (UNSD) with input from the InterAgency and Expert Group on SDG Indicators (IAEG-SDGs). Retrieved from: https://unstats.un.org/unsd/statcom/52nd-session/documents/BG-3aPractical_ guidebook_on_data_disaggregation_for_the_SDGs-E.pdf 2021

20. Sachs, J. D., Schmidt-Traub, G., \& Lafortune, G. (2020). Speaking truth to power about the SDGs. Nature, 584(7821), 344-354.

21. Sachs, J., Schmidt-Traub, G., Kroll, C., Durand-Delacre, D., \& Teksoz, K. (2017). SDG Index and dashboards repo16rt. Bertelsmann Stiftung and Sustainable Development Solutions Network, New York.

22. The Center for Open Data Enterprise and Open Data Watch (2019). SDG Reporting Platforms: New Progress and Priorities. Global Partnership for Sustainable Development Data. Retrieved from: http://www.data4sdgs.org/news/sdg-reportingplatforms-new-progress-and-priorities

23. UNCTAD (2014). Developing countries face \$2.5 trillion annual investment gap in key sustainable development sectors. UNCTAD report estimates. United Nations Conference on Trade and Development: Geneva, Switzerland. 
24. United Nations (2019). IAEG-SDGs Tier classification for Global SDG indicators [Online]. Retrieved from: https://unstats.un.org/sdgs/iaeg-sdgs/tier-classification/.

25. Weber, O. (2018). The Financial Sector and the SDGs: Interconnections and Future Directions. Retrieved from: https://www.cigionline.org/sites/default/files/documents/ Paper\%20No.201web.pdf. 